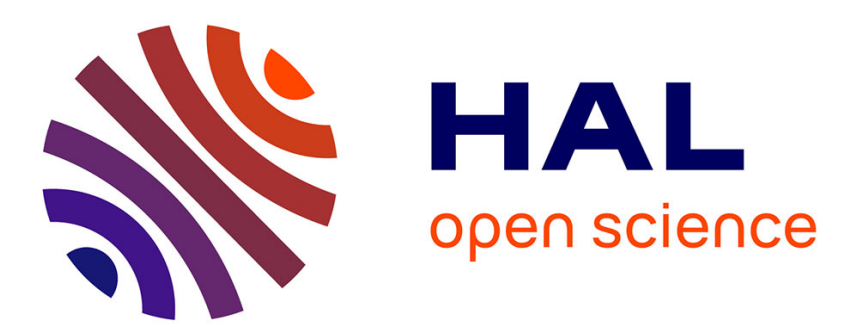

\title{
Simulation of Chemical Vapour Deposition of SiC from Methyltrichlorosilane in a Hot Wall Reactor
}

\author{
D. Neuschütz, M. Schierling, S. Zimdahl
}

\section{To cite this version:}

D. Neuschütz, M. Schierling, S. Zimdahl. Simulation of Chemical Vapour Deposition of SiC from Methyltrichlorosilane in a Hot Wall Reactor. Journal de Physique IV Proceedings, 1995, 05 (C5), pp.C5-253-C5-260. 10.1051/jphyscol:1995529 . jpa-00253854

\section{HAL Id: jpa-00253854 https://hal.science/jpa-00253854}

Submitted on 1 Jan 1995

HAL is a multi-disciplinary open access archive for the deposit and dissemination of scientific research documents, whether they are published or not. The documents may come from teaching and research institutions in France or abroad, or from public or private research centers.
L'archive ouverte pluridisciplinaire HAL, est destinée au dépôt et à la diffusion de documents scientifiques de niveau recherche, publiés ou non, émanant des établissements d'enseignement et de recherche français ou étrangers, des laboratoires publics ou privés. 


\title{
Simulation of Chemical Vapour Deposition of SiC from Methyltrichlorosilane in a Hot Wall Reactor
}

D. Neuschütz, M. Schierling and S. Zimdahl

Lehrstuhl für Theoretische Hüttenkunde, RWTH Aachen, 52066 Aachen, Germany

\begin{abstract}
A two-dimensional simulation for the deposition of SiC from gas mixtures containing MTS- $\mathrm{H}_{2}-\mathrm{HCl}$-Ar was set up on the basis of the commercial CFD-code PHOENICS (1.6.6). Previously measured rate equations [1] that describe the deposition reaction were implemented. Allowing deposition on all surfaces in the reactor the model takes into account the influence of local depletion of MTS and enrichment of $\mathrm{HCl}$ during deposition also upstream of the substrate. In the range from 800 to $1400{ }^{\circ} \mathrm{C}$ the calculated total mass increase rates on the substrate as a function of temperature, partial pressure and flow rate show good agreement with experiments. The simulation model was then used to calculate local deposition rates with the aim of finding suitable conditions to produce uniform layer thickness.
\end{abstract}

\section{INTRODUCTION}

Production of SiC coatings and SiC matrix composites using chemical vapour deposition (CVD) is a well introduced technology. One possible reactant currently used in commercial operations is methyltrichlorosilane (MTS) in the presence of $\mathrm{H}_{2}[2,3,4,5]$. Especially in the case of chemical vapour infiltration (CVI) the knowledge of appropriate process parameters is required to achieve good infiltration and low residual porosities. In-advance calculation of the local deposition rates is therefore of particular interest.

Deposition rates are often determined in a complex way by interaction of both gas phase and surface reactions and transport processes. In order to describe the transport phenomena computational fluid dynamic codes have gained increasing importance in recent years. Modelling of the chemistry is usually done assuming local thermodynamic equilibrium or kinetically limited reaction rates. Simulation of CVD processes considering transport phenomena combined with chemistry modelled by kinetically limited rate equations were carried out for the deposition of e.g. silicon, gallium arsenide and tungsten $[6,7,8,9]$. 
In the case of deposition of $\mathrm{SiC}$ from MTS the formulation of local thermodynamic equilibrium showed to be of little relevance for the description of the deposition process. In this system modelling of gas phase and heterogeneous chemistry by rate equations has been carried out by several research groups $[10,11,12,13]$. Results for modelling the homogeneous gas reactions give the order of magnitude of the reaction rates. The modelling of heterogeneous reactions is even more difficult so that quantitative prediction of the deposition rate is still not possible.

In the present work a simulation of the $\mathrm{SiC}$ deposition rate is presented which makes use of rate equations describing the deposition reaction as determined previously in this laboratory [1]. The rate equations are implemented in the CFD code PHOENICS (1.6.6). With these equations and the description of the transport processes in the gas phase the simulations showed good agreement with experimental observations in wide ranges of operating parameters. In this state of modelling it proved unnecessary to include the calculation of thermodynamic equilibrium.

\section{EXPERIMENTAL REFERENCE}

The simulation is based on experimental results obtained previously in this laboratory [1]. The deposition rate of $\mathrm{SiC}$ was measured with a magnetically coupled themobalance as described before $[14,15]$. The reactor geometry used for experiments and simulation is given in Fig. 1 . The experimental conditions are summarized in Table 1.

Table 1: Experimental conditions for SiC deposition

\begin{tabular}{|c|c|}
\hline Feedgas mixture: & $\begin{array}{ll}0,9-8,1 \% \mathrm{CH}_{3} \mathrm{SiCl}_{3} & \text { (methyltrichlorosilane = MTS) } \\
0,9-8,1 \% \mathrm{H}_{2} & \text { with }\left[\mathrm{H}_{2}\right] /[\mathrm{MTS}]=1 \\
0,0-0,7 \% \mathrm{HCl} & \\
\text { balance } \mathrm{Ar} & \end{array}$ \\
\hline Reactor type: & Vertical tubular hot wall, \\
\hline Flowrate: & $100-200 \mathrm{l}_{\mathrm{STP}} / \mathrm{h}$, atmospheric pressure \\
\hline Temperatures: & $800-1400^{\circ} \mathrm{C}$ \\
\hline Substrate: & Graphite plates, $10 \times 50 \times 2 \mathrm{~mm}^{3}$ \\
\hline Solid product: & B- SiC \\
\hline
\end{tabular}

A reaction order of 1 for MTS and an apparent activation energy of $380 \mathrm{~kJ} / \mathrm{mol}$ was found. With respect to $\mathrm{HCl}$ two different reaction orders were found:

-1 in the region of $[\mathrm{MTS}] /[\mathrm{HCl}]>5,8$ and -3 in the region of $[\mathrm{MTS}] /[\mathrm{HCl}]<5,8$.

\section{SIMULATION}

A model was set up on the basis of the commercial CFD-code PHOENICS (Version 1.6.6) in order to simulate the steady state reactor operation by numerical integration of the partial 
differential equations for conservation of mass, heat, momentum and species.

\subsection{Properties}

Viscosity, heat capacity and thermal conductivity data for pure substances as a function of temperature were taken from the DIPPR data bank [16]. The corresponding properties for the gas mixtures and the multicomponent diffusion coefficients were calculated following well established methods of kinetic theory [17]. The actually employed methods are listed elsewhere [18]. For economy in computing time the following simplifications were made: The heat capacity $c_{p}$ was calculated from feedgas composition rather than from local composition. The Diffusion coefficients $\mathrm{D}$ were handled in PHOENICS in form of a Schmitt number $\mathrm{Sc}=\eta /(\boldsymbol{\rho} \cdot \mathrm{D})$ and the thermal conductivity $\lambda$ is made available to

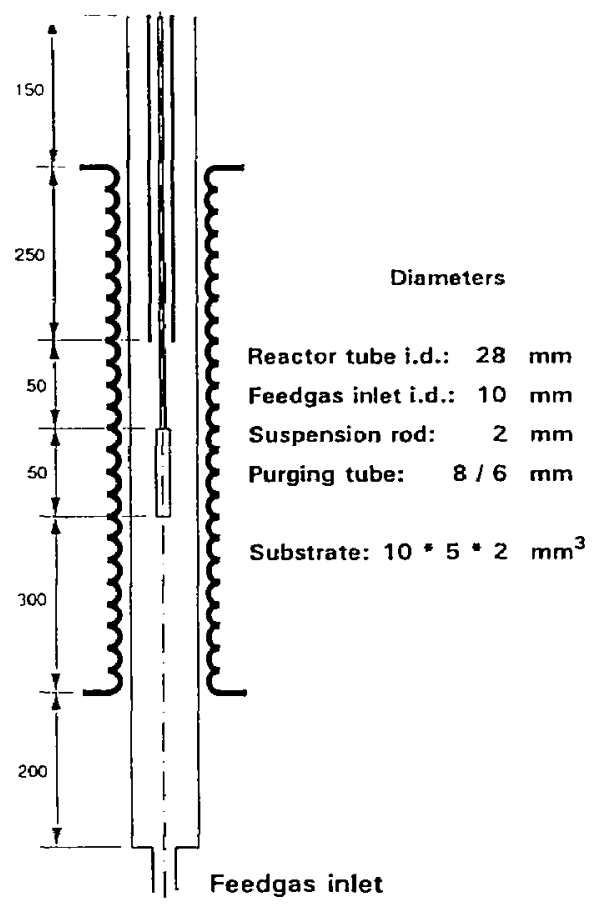
PHOENICS in form of a Prandtl number $\operatorname{Pr}=\left(\eta \cdot c_{p}\right) / \lambda$. Both Sc and Pr were calculated from the feedgas composition and feedgas temperature and subsequently treated as constants. Due to the opposing influence of temperature on the properties which effect the Schmitt- and Prandtl numbers the deviation of this procedure from locally calculated values does not exceed $5 \%$ in the case of Sc and $25 \%$ in the case of Pr.

The density $\rho$ was calculated according to the ideal gas law. For all conditions investigated flow could be assumed to be laminar and buyoancy forces could be neglected.

\subsection{Geometry and grid}

The geometry of the reactor being axisymmetric a two-dimensional model was set up. Calculations were carried out for a cylindrical substrate of the same length and surface area as the original rectangular substrate. For the simulation a grid was fitted to the reactor geometry with the size of the cells being reduced in the vicinity of solid surfaces. Results proved to be grid independent with 32 cells in radial and 72 cells in axial direction.

\subsection{Boundary conditions}

Along the boundary at the symmetry axis of the reactor tube the radial gradients of velocity. concentration or temperature were taken as zero. 


\subsubsection{Energy}

At reactor and substrate walls a constant parabolic temperature profile in axial direction was assumed based on experimental data. At the reactor inlet and outlet the temperature was set to $25^{\circ} \mathrm{C}$ and no axial gradients were assumed. Heats of reaction were neglected.

\subsubsection{Mass and momentum}

At the reactor inlet a constant feedgas flow rate was prescribed, the pressure at the reactor outlet was taken as 1 bar. No slip was assumed for the velocity components.

\subsubsection{Species and chemical reactions}

Constant inlet concentrations were prescribed for all species, at the outlet no axial gradients were assumed. The species balanced were $\mathrm{MTS}, \mathrm{HCl}$ and $\mathrm{H}_{2}$. Gas phase reactions were not taken into account. The only chemical reaction accounted for in the model is the heterogeneous deposition reaction

$$
\mathrm{MTS}=\mathrm{SiC}+3 \mathrm{HCl}
$$

taking place on solid surfaces, either reactor wall or substrate. Its rate was taken from experimental measurements [1] which delivered two rate equations, where brackets denote concentrations: and

$$
\mathbf{j}_{\mathrm{SiC}}(\mathrm{I})=\mathbf{k}_{\mathrm{I}}[\mathrm{MTS}][\mathrm{HCl}]^{-1} \exp \left(-\mathrm{A}_{\mathrm{I}} / \mathrm{RT}\right) \text { for region } \mathrm{I} \text { at }[\mathrm{MTS}] /[\mathrm{HCl}]>5,8,
$$$$
\mathrm{j}_{\mathrm{SiC}}(\mathrm{II})=\mathrm{k}_{\Pi}[\mathrm{MTS}][\mathrm{HCl}]^{-3} \exp \left(-\mathrm{A}_{\Pi} / \mathrm{RT}\right) \text { for region I at }[\mathrm{MTS}] /[\mathrm{HCl}]<5,8
$$

The activation energies $A_{I}$ and $A_{\Pi}$ were experimentally determined to be equal amounting to about $380 \mathrm{~kJ} / \mathrm{mol}$.

For the present simulation it has been assumed that these two rate equations describe two consecutive steps of the deposition reaction of which the slower one is rate-determining. Therefore, the rates $\mathrm{j}_{\mathrm{SiC}}(\mathrm{I})$ and $\mathrm{j}_{\mathrm{SiC}}$ (II) were calculated for each set of conditions (temperature, [MTS] and [HCI]) and the lower values obtained in each case were used as the actual deposition rates. Calculations showed that modification of the activation energy of $380 \mathrm{~kJ} / \mathrm{mol}$ to $A_{I}=420 \mathrm{~kJ} / \mathrm{mol}$ and $A_{I I}=385 \mathrm{~kJ} / \mathrm{mol}$ including the respective adaptation of $\mathrm{k}_{\mathrm{I}}$ and $\mathrm{k}_{\mathrm{II}}$ yielded better agreement between simulation and experiment.

\subsection{Solution procedure}

Solution was achieved calculating slab-by-slab with the built-in linear equation solver. Convergence for species conservation was judged by the whole field residual sums (normalized by the maximum value and number of grid points) being less than $10^{-8}$ and by checking the global mass balances. Results were accepted with a mass balance error less than $0.2 \%$. 


\subsection{Results}

Figures 2 - 5 show simulation results together with experimental observations [1]. Here deposition rate is expressed as the mass increase rate integrated over the total surface of the substrate. In Fig, 4 the symbols marked with an arrow give experimental deposition rates obtained with $\mathrm{P}_{\mathrm{HCl}}=0$ in the feedgas. Also the curve for the simulated deposition rates is extended to the values for $\mathrm{p}_{\mathrm{HCl}}=0$ in the feedgas (dashed line).

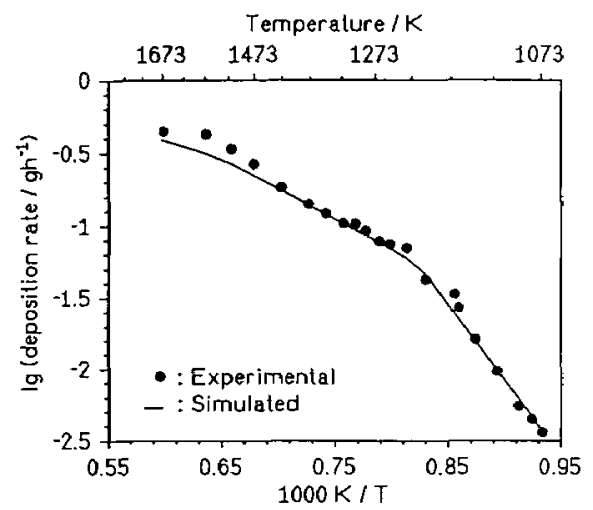

Fig. 2: Temperature influence on deposition rate at $150 \mathrm{l}_{\mathrm{STP}} / \mathrm{h}$ flow rate and $\mathrm{p}_{\mathrm{HCl}, \text { feed }}=0$, $\mathrm{P}_{\mathrm{MTS}}$, feed $=17,9$ mbar

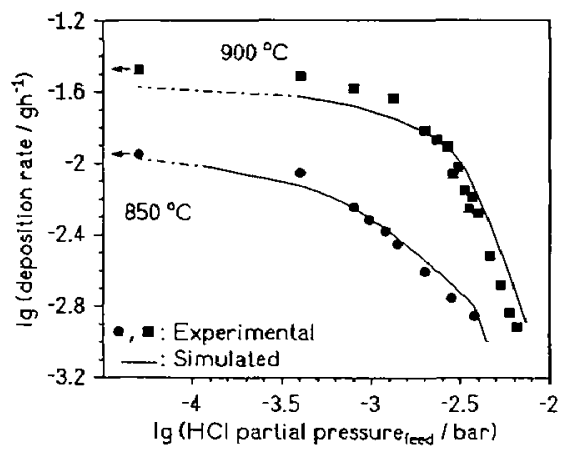

Fig. 4: $\mathrm{HCl}$ influence on deposition rate at $150 l_{\mathrm{STP}} / \mathrm{h}$ flow rate and $P_{\text {MTS, feed }}=17,9$ mbar

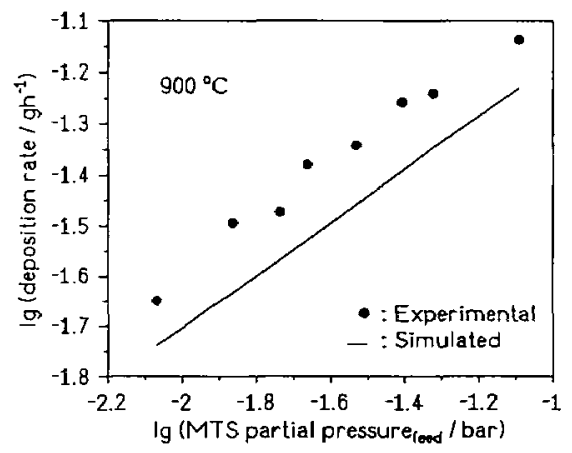

Fig. 3: MTS influence on deposition rate at $150 \mathrm{l}_{\mathrm{STP}} / \mathrm{h}$ flow rate and $\mathrm{p}_{\mathrm{HCl}, \text { feed }}=0$

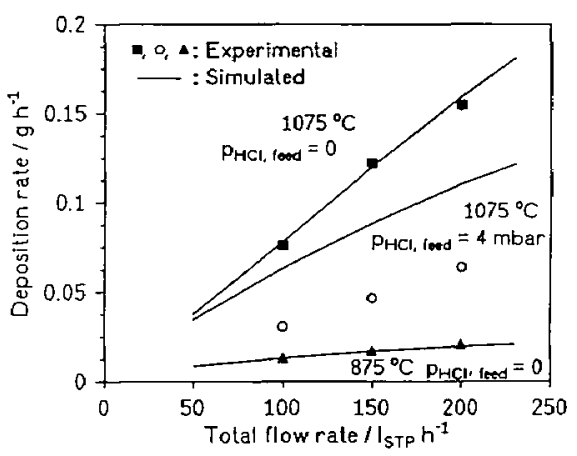

Fig. 5: Total flow rate influence on deposition rate at $\mathrm{P}_{\mathrm{MTS}}$, feed $=17,9 \mathrm{mbar}$

Figures 6 and 7 show simulated results for the local deposition rates along the substrate. Partial pressures of $\mathrm{HCl}$ at the upstream $(0 \mathrm{~mm})$ and downstream end $(50 \mathrm{~mm})$ of the substrate are given to show the strong connection between deposition rate and local $\mathrm{HCl}$ concentration. MTS partial pressures at the downstream end of the substrate are given to show the degree of MTS depletion, starting from 17,9 mbar in the feedgas. Fig. 6 describes the local deposition rates for gas mixtures initially free of $\mathrm{HCl}$, and $\underline{\mathrm{Fig}, 7}$ gives examples for gases with increasing $\mathrm{HCl}$ contents in the feedgas: The absolute deposition rates decrease strongly, but the local rates vary much less along the length of the substrate. 


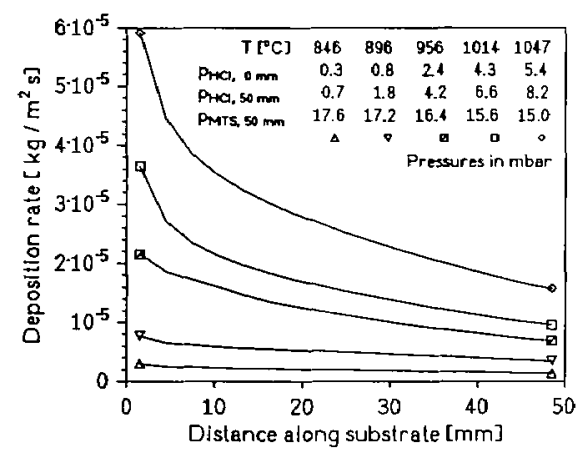

Fig. 6: Simulated local deposition rate along substrate at $150 \mathrm{l}_{\mathrm{STP}} / \mathrm{h}$ flow rate and PMTs, feed $=17,9$ mbar, $\mathrm{p}_{\mathrm{HCl}, \text { feed }}=0$

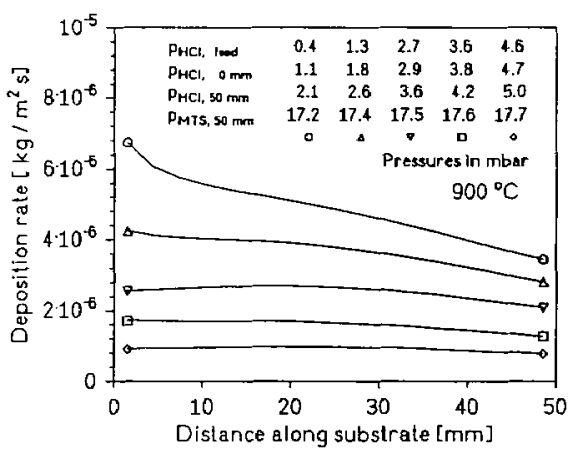

Fig. 7: Simulated local deposition rate along substrate at $150 \mathrm{l}_{\mathrm{STP}} / \mathrm{h}$ flow rate and $\mathrm{P}_{\mathrm{MTS}, \text { feed }}=17,9$ mbar at different $\mathrm{HCl}$ concentrations in the feedgas

\section{DISCUSSION}

Fig, 2 shows that for temperatures up to $1150^{\circ} \mathrm{C}$ and for feedgases free of $\mathrm{HCl}$ agreement of simulation with experiment is very close. Also excellent agreement is found for the influence of total flow rate for feedgas free of $\mathrm{HCl}$ at both high and low temperatures (Fig.5). MTS depletion during the process reaches some $15 \%$ at the end of the substrate for deposition at $1047^{\circ} \mathrm{C}$ (Fig, 6). From Fig, 3 can be seen that the simulation model is capable to describe the effect of MTS variations over a much wider range than that caused by consumption. The cases given in Fig. 2 and 3 always include consideration of the retarding effect of $\mathrm{HCl}$ developed in situ. Fig. 4 shows the influence of $\mathrm{HCl}$ amounts already added to the feedgas mixture. For deposition at $850^{\circ} \mathrm{C}$ and up to $\mathrm{p}_{\mathrm{HCl}}=4,7$ mbar in the feedgas the reaction rate at the substrate is governed by rate equation (I). $\mathrm{HCl}$ partial pressures higher than $4,7 \mathrm{mbar}$ lead to a deposition along the substrate governed by rate equation II. This is indicated by the steeper gradient of the curve. For deposition at $900{ }^{\circ} \mathrm{C}$ (Fig. 4 and 7) transition from rate equation (I) to rate equation (II) at the substrate occurs between $\mathrm{p}_{\mathrm{HCl}}=2,7$ and $3,6 \mathrm{mbar}$ in the feedgas.

Fig. 6 illustrates the effect of $\mathbf{H C l}$ developed in situ retarding the deposition rate. The deposition rates at the upstream and downstream ends of the substrate vary by a factor of 2,5 .. 3 at all temperatures. Fig. 7 shows that these effects of $\mathrm{HCl}$ enrichment on the local variation of deposition rate decrease with $\mathrm{HCl}$ additions to the feedgas. The curves for $\mathrm{HCl}$ partial pressures in the feedgas being equal or higher than 2,7 mbar exhibit the dominating influence of the parabolic temperature profile on the deposition rate along the substrate. Unfortunately this higher uniformity in deposition is related to a much lower deposition rate.

Inspite of the simple approach chosen to describe the deposition reaction the simulation shows good agreement with the experimental observations. The deviations observed may to a greater part be due to the simplifications made in describing the reaction chemistry. 


\section{CONCLUSION}

The deposition of $\mathrm{SiC}$ from gas mixtures containing $\mathrm{MTS}-\mathrm{H}_{2}-\mathrm{HCl}-\mathrm{Ar}$ was simulated. In the simulation model the chemical reaction is accounted for by two rate equations describing the local SiC deposition rate as a function of temperature and the concentrations of MTS and $\mathrm{HCl}$. These rate equations for local deposition of $\mathrm{SiC}$ were derived from mass increase rates integrated over the total surface of a $50 * 10 * 2 \mathrm{~mm}^{3}$ substrate (integral deposition rates) [1]. The reaction rate equations together with modelling of transport in multicomponent gas mixtures [18] were implemented to the CFD code PHOENICS (1.6.6). The simulated deposition rates of $\mathrm{SiC}$ were found in good agreement with experiments over a wide range of deposition parameters. Furthermore it was shown that a very simplified description of the deposition chemistry in combination with gas transport modelling was already able to yield good simulation results. The assumption of the two rate equations describing two consecutive steps in the deposition reaction proved to be justified. With the incorporation of appropriate modelling of porosity an application of this simulation model to CVI processes appears to be feasible.

Deviations of simulation from experiment indicate that for a better agreement the description of the deposition chemistry should be expanded and include e.g. homogeneous gas phase reactions.

The simulations showed, that the obstructing effect of $\mathrm{HCl}$ on deposition uniformity decreased with $\mathrm{HCl}$ additions to the feedgas. Special advantage of this modified process is seen in the area of chemical vapour infiltration and coating of complex geometries. An alternative to obtain better uniformity of deposition might be the use of chlorine-free precursor systems.

\section{ACKNOWLEDGEMENTS}

The development of the CVD simulation model was financially supported by the Arbeitsgemeinschaft industrieller Forschungsvereinigungen e.V. (AIF No. 23:9052 B/1), the European Community (ERBSC1*CT920774, Computer Aided Process Simulation) and the

Deutsche Forschungsgemeinschaft (Collaborative Research Center 370 "Integrative Werkstoffmodellierung").

\section{REFERENCES}

[1] Delhaes C., Neuschütz D., "Rate of SiC deposition from methyltrichlorosilane and influence of $\mathrm{HCl}$ addition", MRS Fall Meeting, Boston MA, Nov. 1994

[2] Besman T.M., Sheldon B.W., Lowden R.A., Stinton D.P., Science, (Washington DC), 253, pp 1101-1109 (1991)

[3] Naslain R., Langlais F., Fedou R., The CVI-Processing of Ceramic Matrix Composites, J. Phys., Colloq., 50, pp 191-207 (1989)

[4] So M.G., Chun J.S., "Growth and structure of chemical vapor deposited silicon carbide from methyltrichlorosilane and hydrogen in the temperature range of 1100 to $1400{ }^{\circ} \mathrm{C} "$, J.Vac.Sci.Technol. ,A, Vol. 6, N 1 , pp 5-8 (1988)

[5] Chiu C.C., Desu S.B., Tsai C.Y., "LPCVD of $\beta$-SiC on Si(100) using MTS in a hot wall reactor", J.Mater.Res., Vol. 8, N¹0, pp 2617-2626 (1993) 
[6] Kleijn C.R., "A mathematical model of the hydrodynamics and gas-phase reactions in silicon LPCVD in a single wafer reactor", J.Electrochem.Soc., Vol. 138, $\mathrm{N}^{\circ} 7$, pp 2190-2200 (1991)

[7] Mountziaris J., Jensen K.F., "Gas-phase and surface reaction mechanisms in MOCVD of GaAs with trimethylgallium and arsine", J.Electrochem.Soc., Vol. 138, $\mathrm{N}^{\circ} 8$, pp 2426-2439 (1991)

[8] Wang Y.B., Teyssandier F., Simon J., Feurer R., "Chemical vapor deposition of silicon from disilane under reduced pressure in a circular impinging jet reactor. Simulation and experiments", J.Electrochem.Soc., Vol. 141, $\mathbf{N}^{\circ} 3$, pp 824-842 (1994)

[9] Tirtowidjojo M., Pollard R., "Elementary processes and rate limiting factors in MOVPE of GaAs", J.Cryst.Growth, Vol. 93, pp 108-114 (1988)

[10] Osterheld T.H., Allendorf M.D., Melius C.F., "Unimolecular decomposition of methyltrichlorosilane: RRKM Calculations", J.Phys.Chem., Vol. 141, N6, pp 15991611 (1994)

[11] Papasouliotis G.D., Sotirchos S.V., "On the homogeneous chemistry of the thermal decomposition of methyltrichlorosilane. Thermodynamic analysis and kinetic modeling", J.Electrochem.Soc., Vol. 141, N6, pp 1599-1611 (1994)

[12] Tsai C.Y., Desu S.B., Chiu C.C., "Kinetic study of silicon carbide deposited from methyltrichlorosilane precursor", J.Mater.Res., Vol. 9, N¹, pp 104-111 (1994)

[13] Besman T.M., Sheldon B.W.,Moss III T.S., Kaster M.D., J. Am. Ceram. Soc., 75 (10), 1992, pp 2899-903

[14] Neuschütz D., Salehomoum F., Chemical Vapour Deposition of Refractory Metals and ceramics II, edited by T.M. Besman, B.M. Gallois, J.W. Warten (Mater. Res. Soc. Proc. 250, Pittsburgh, PA, 1992) pp.41-46

[15] Neuschütz D., Zimdahl S., Zimmermann E., Proc. Twelfth Int. Symp. Chem. Vap. Deposition, edited by K.F. Jensen and G.W. Cullen (The Electrochemical Soc. Proc. Vol 93-2, Pennington, NJ, 1993) pp. 1-7

[16] Design Institut for Physical Property Data, DIPPR, American Institute of Chemical Engineers, 345 E. $47^{\text {th }}$ Street, New York, NY 10017

[17] Reid R.C., Prausnitz J.M., Poling B.E., The Properties of Liquids and Gases, 4. Ed., McGraw-Hill, New York, 1987

[18] Zimdahl S., Messungen und Simulationen zur kinetisch kontrollierten Erzeugung dünner Schichten nach dem CVD-Verfahren, Fortschritt-Berichte VDI Reihe $5 \mathrm{Nr}$ 368, VDI-Verlag, Düsseldorf, Germany, 1994 